\title{
Publisher Correction: Listeners' perceptions of the certainty and honesty of a speaker are associated with a common prosodic signature
}

\author{
Louise Goupil(1D, Emmanuel Ponsot, Daniel Richardson, Gabriel Reyes \& Jean-Julien Aucouturier
}

Correction to: Nature Communications https://doi.org/10.1038/s41467-020-20649-4, published online 8 February 2021.

The original version of the Supplementary Information associated with this Article contained errors in Supplementary Figures 1, 3, 4, 5, 7 and 8 and an error in the figure legend of Supplementary Figure 8. The HTML has been updated to include a corrected version of the Supplementary Information; the original incorrect version of the Supplementary Information file can be found as Supplementary Information associated with this Correction.

Published online: 27 September 2021

\section{Additional information}

Supplementary information The online version contains supplementary material available at https://doi.org/10.1038/s41467-021-25958-w.

\begin{abstract}
(c) (i) Open Access This article is licensed under a Creative Commons Attribution 4.0 International License, which permits use, sharing, adaptation, distribution and reproduction in any medium or format, as long as you give appropriate credit to the original author(s) and the source, provide a link to the Creative Commons license, and indicate if changes were made. The images or other third party material in this article are included in the article's Creative Commons license, unless indicated otherwise in a credit line to the material. If material is not included in the article's Creative Commons license and your intended use is not permitted by statutory regulation or exceeds the permitted use, you will need to obtain permission directly from the copyright holder. To view a copy of this license, visit http://creativecommons.org/licenses/by/4.0/.
\end{abstract}

(c) The Author(s) 2021 